\title{
Changes in Lipids and Electrolyte Leakage during Nonnetted Muskmelon Ripening
}

\author{
Dominique Lacan and J.C. Baccou \\ Laboratoire de Physiologie et Technologie des Végétaux CC 024, Université de Montpellier II, 34095 \\ Montpellier Cedex 5 France \\ Additional index words. ethylene, lipids, muskmelon, permeability, respiration, ripening

\begin{abstract}
Respiration, $\mathrm{C}_{2} \mathrm{H}_{4}$ production, lipid composition, and electrolyte leakage were monitored during ripening of two nonnetted muskmelon (Cucumis melo $\mathrm{L}$.) varieties differing in their storage life: 'Clipper' (a long-storage-life variety) and 'Jerac', which was used as a control. Respiration rates were comparable in both varieties. Although 'Jerac' exhibited normal climacteric $\mathrm{C}_{2} \mathrm{H}_{4}$ production, 'Clipper' continued to produce significant amounts of $\mathrm{C}_{2} \mathrm{H}_{4}$ until senescence. Electrolyte leakage increased with ripening and was always higher in 'Jerac'. The loss of membrane integrity seems to be related to changes in the lipid composition due to a breakdown of phospholipids, an increase of sterol synthesis, and an increase in fatty acid saturation. On the contrary, in 'Clipper', the absence of a major change in sterol and phospholipids content and the high level of fatty acid unsaturation suggest that membrane permeability is not greatly affected during ripening. This is consistent with the low loss of solutes measured and may delay senescence in 'Clipper' fruit.
\end{abstract}

In most climacteric fruit like muskmelon, ripening is associated with increased respiration and $\mathrm{C}_{2} \mathrm{H}_{4}$ biosynthesis and is accompanied by many visual and physiological changes (Brady, 1987). This process is now considered as a phase of reorganization rather than disorganization of tissues because it is the result of the synthesis and degradation of cell components (Romani, 1984).

Among the mechanisms involved in fruit ripening, changes in membrane structure play an important role because they lead to increased the membrane permeability and alter the activity of membrane-bound enzymes.

Changes in membrane function have been followed in tomato tissues (Güçlü et al., 1989), in apple microsomal fractions (Lurie and Ben-Arie, 1983), or in apple isolated membranes (Lurie et al., 1987) and corresponded, at least in part, to changes in lipid composition. These authors reported a correlation between changes in lipid composition, particularly in the sterol-phospholipid ratio and membrane permeability. However, in muskmelons, Lester and Stein (1993) showed that biochemical changes that affect membrane lipid composition could influence storage life.

Therefore, the purpose of this work was to follow $\mathrm{C}_{2} \mathrm{H}_{4}$ synthesis, $\mathrm{CO}_{2}$ production, and changes in the lipid composition of mesocarp tissues in two nonnetted muskmelon varieties differing in storage life: 'Clipper' a long storage variety (>14 days) and 'Jerac' ( $<7$ days), which was used as a standard. Ethylene and $\mathrm{CO}_{2}$ were used as physiological ripening markers. Moreover, we proposed to correlate these metabolic events to their storage life and to compare changes in lipid composition with changes in membrane permeability.

\section{Materials and Methods}

Plant material. Nonnetted muskmelons were grown in a greenhouse. Plant flowers were hand-pollinated and two fruit per plant were allowed to develop. 'Clipper', type Vauclusien (Nunhems, Netherlands), and 'Jerac' (Tezier, France) muskmelons were obtained from Eyragues (France) and harvested at the beginning of

Received for publication 11 Sept. 1995. Accepted for publication 14 Feb. 1996 This work was supported by Bio-Obtentions Society (France). We acknowledge Philippe Roch (A.S.L., France) and Alain Dreyer (Bio-Obtentions, France) for technical assistance and useful discussions. The cost of publishing this paper was defrayed in part by the payment of page charges. Under postal regulations, this paper therefore must be hereby marked advertisement solely to indicate this fact. physiological maturity (about 37 days after full bloom). Fruit classified at maturity were green-yellow. The fruit were weighed and stored in a room held at $25 \mathrm{C}, 85 \%$ relative humidity $(\mathrm{RH})$. All data are means from five experiments (an experiment corresponding to a growing). For each experiment, five assays were run with five fruit per assay and variety.

Determining $\mathrm{C}_{2} \mathrm{H}_{4}$ and $\mathrm{CO}_{2}$ production. Ethylene and $\mathrm{CO}_{2}$ production were measured following Güçlü et al. (1989). Fruit from each variety were sampled for analysis each day or as needed, and their $\mathrm{CO}_{2}$ and $\mathrm{C}_{2} \mathrm{H}_{4}$ evolution were determined by enclosing each fruit in a 3-liter jar. Samples were drawn from the container atmosphere after $1 \mathrm{~h}$ and analyzed for $\mathrm{CO}_{2}$ using a Girdel gas chromatograph (GC) (Suresnes, France) with a catharometer detector. The carrier gas was argon $\left(30 \mathrm{ml} \cdot \mathrm{min}^{-1}\right)$. The detector temperature was $40 \mathrm{C}$ and the oven temperature was $35 \mathrm{C}$. Data were expressed as $\mathrm{ml} \mathrm{CO} / \mathrm{kg}$ fresh weight per $\mathrm{h}$. Ethylene in gas samples was analyzed by GC (Shimadzu CR6A) equipped with a Porapak T column $(60 \times 0.32 \mathrm{~cm})$ at $80 \mathrm{C}$ with a $\mathrm{N}_{2}$ carrier at 20 $\mathrm{ml} \cdot \mathrm{min}^{-1}$ and a flame ionization detector (FID). Oven temperature was held at $70 \mathrm{C}$. For measuring $\mathrm{CO}_{2}$ and $\mathrm{C}_{2} \mathrm{H}_{4}$ production on fruit attached to plants, fruit were enclosed in a hermetically sealed plastic bag, Data were expressed as $\mu \mathrm{C} \mathrm{C}_{2} \mathrm{H}_{4} / \mathrm{kg}$ fresh weigh per h.

Isolating microsomes. Five grams of mesocarp pulp was homogenized with a Turrax homogenizer in $150 \mathrm{mlEPPS}, \mathrm{pH} 8.5$ (Droillard et al., 1987). The homogenate was filtered through five layers of Miracloth and centrifuged at $12,000 \times g$ for $30 \mathrm{~min}$. The supernatant was then centrifuged at $130,000 \times g$ for $1 \mathrm{~h}$ to obtain microsomal membrane pellets that were resuspended in 2 mM EPPS, $\mathrm{pH} 8.5$.

Determining electrolyte leakage. Ten hypodermal-mesocarp discs ( $10 \mathrm{~mm}$ wide, $2 \mathrm{~mm}$ thick) were incubated in 50-ml Erlenmeyer flasks at $20 \mathrm{C}$ in $25 \mathrm{ml} 0.6 \mathrm{~m}$ sorbitol and $10 \mathrm{~mm}$ potassium phosphate, pH 6 (Lester, 1990; Lurie and Klein, 1990). The conductivity of the solution was measured at time 0 and after $3 \mathrm{~h}$ using a radiometer conductometer (Copenhagen, Denmark). Total electrolytes were determined in the same solution after mixing the discs with a Turrax homogenizer (Janke \& Kunkel, Germany) and then filtering through two layers of Miracloth. Results are expressed as percentage of total electrolytes.

Analyzing lipids. Lipids were extracted according to Bligh and Dyer (1959) from lyophylized samples in 0.8 water : 1 chloroform : 2 methanol (by volume).

Aliquots from the total lipid fraction were taken for analyzing 
total phospholipid content. Phospholipids were determined colorimetrically by $\mathrm{P}$ analysis according to Ames (1966), and the results were expressed in $\mathrm{mg} \cdot \mathrm{g}^{-1}$ dry weight. Fatty acids were measured in the phospholipid fraction isolated from the total lipid extract by thin-layer chromatography using 80 hexane : 20 ether : 1 acetic acid (by volume). The part containing phospholipids was removed, eluted with 1 chloroform : 1 methanol (by volume), dried under $\mathrm{N}_{2}$, and then methylated. The fatty acid methyl esters were analyzed on a GC-FID (Delsi 700, Suresnes, France) using a superox column (Alltech, Paris, France) $30 \mathrm{~m}$ long and $0.25 \mathrm{~mm}$ in diameter. The carrier gas was $\mathrm{H}_{2}$. The detector temperature was $250 \mathrm{C}$ and the injector temperature was $240 \mathrm{C}$. The temperature program was 180 to $240 \mathrm{C}, 4 \mathrm{C} / \mathrm{min}$. Reference methylated fatty acids were run for identification purposes.

Total sterols were isolated from the total lipid fraction according to the method of Grunwald (1970) after incorporating betulinol as an internal standard. Sterols purified by TLC were acetylated and analyzed on the GC-FID using a DB 1 column (Alltech, Paris, France) $30 \mathrm{~m}$ long and $0.25 \mathrm{~mm}$ in diameter. Column oven, injector, and detector were 280 (isothermal), 300, and 300C respectively. Carrier gas flow rate was $1.1 \mathrm{ml} \cdot \mathrm{min}^{-1}$. Retention times were compared with authentic cholesterol, campesterol, stigmasterol, and sitosterol standards.

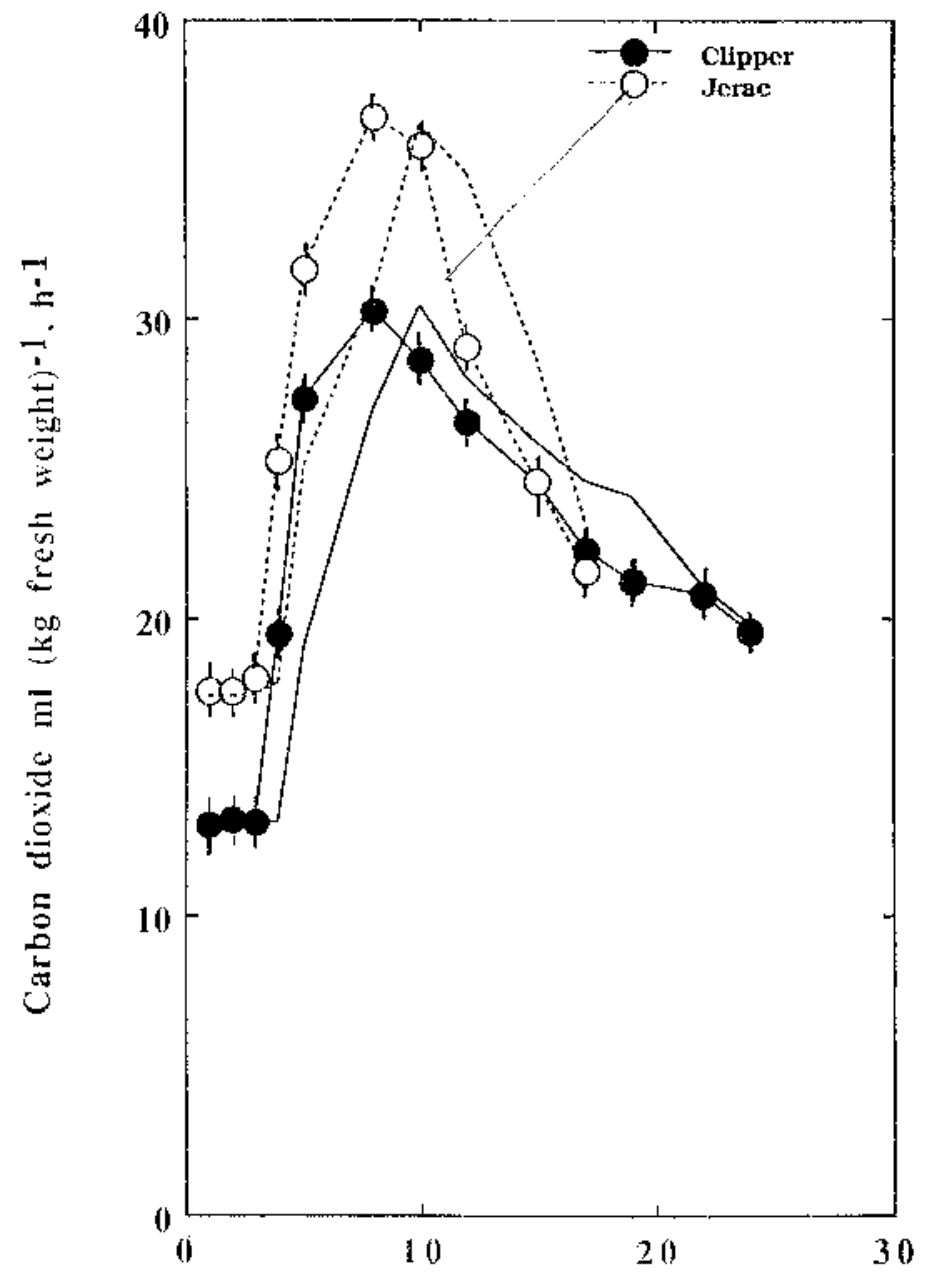

Slorage timere (days)

Fig. 1. Changes in $\mathrm{CO}_{2}$ level during ripening of nonnetted muskmelons. Data shown are means of five experiments and $95 \%$ confidence limits. The lines without symbols represent experiments on attached fruit.

\section{Results}

Respiration rate and $\mathrm{C}_{2} \mathrm{H}_{4}$ production. Both varieties exhibited a climacteric increase in $\mathrm{CO}_{2}$ production (Fig. 1) followed by a rise in $\mathrm{C}_{2} \mathrm{H}_{4}$ biosynthesis (Fig. 2). There was no difference in $\mathrm{C}_{2} \mathrm{H}_{4}$ and $\mathrm{CO}_{2}$ production between attached and detached fruit except that both were slightly delayed in detached fruit. The onset of the climacteric occurred by day 3 and $\mathrm{CO}_{2}$ production reached a maximum between day 5 and 7 with about 30 to $40 \mathrm{ml} \cdot \mathrm{kg}^{-1} \cdot \mathrm{h}^{-1}$. At the start of experiments, small amounts of $\mathrm{C}_{2} \mathrm{H}_{4}$ were detected. These amounts were always higher in 'Jerac'. Ethylene levels increased some days later in parallel with the onset of $\mathrm{CO}_{2}$ production. The maximum values were reached on about day 12 . In 'Jerac', $\mathrm{C}_{2} \mathrm{H}_{4}$ production decreased after day 12 , this characterizes the postclimacteric phase. 'Clipper' continued to produce appreciable amounts of $\mathrm{C}_{2} \mathrm{H}_{4}$ after the climacteric increase until fruit senescence.

Electrolyte leakage. Electrolyte leakage is a predictive measure of muskmelon maturation and mesocarp membrane permeability. In both varieties, electrolyte leakage, assayed in sorbitol osmoticum, increased with fruit ripening (Fig. 3). However, the loss of solutes was always greater in 'Jerac' than in 'Clipper', especially in the postclimacteric stage.

Lipid composition. Total sterol content was always higher in

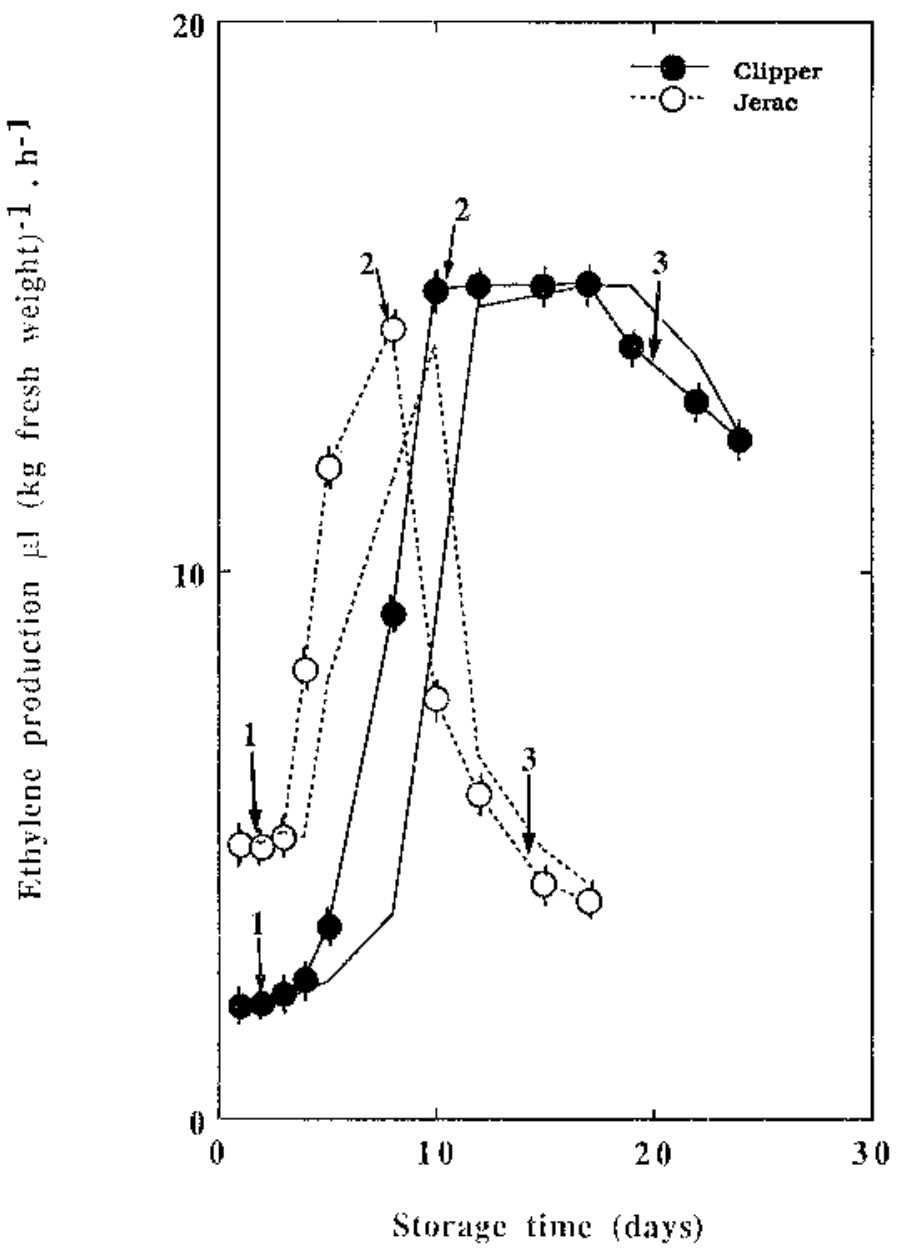

Fig. 2. Changes in $\mathrm{C}_{2} \mathrm{H}_{4}$ production during ripening of nonnetted muskmelons. Data shown are means of five experiments and $95 \%$ confidence limits. Arrows indicate ripening stage: $1=$ preclimacteric stage $2=$ climacteric stage $; 3=$ postclimacteric stage. The lines without symbols represent experiments on attached fruit. 


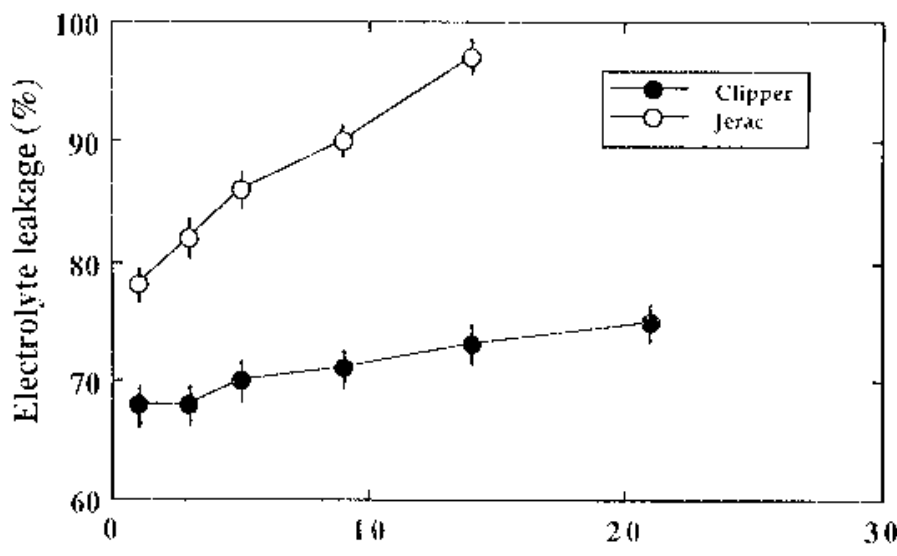

Shorge line (days)

Fig. 3. Efflux of electrolytes into $0.6 \mathrm{M}$ sorbitol solution from hypodermal mesocarp tissues of nonnetted muskmelons. Data shown are means of five experiments and $95 \%$ confidence limits.

'Jerac' than in 'Clipper' (1.5-fold), and there was a substantial increase in the former between the preclimacteric and climacteric stages (Table 1), while in the latter the sterol level remained constant. Phospholipid content was similar in both varieties at the onset of ripening, but decreased in 'Jerac' during the climacteric and postclimacteric stages. As a result of the inverse changes in amounts of sterol and phospholipids in 'Jerac', the sterol-phospholipid ratio increased during the maturation while in 'Clipper' it did not change consistently.

For both varieties, the major free fatty acids were C16:0; C18:0; $\mathrm{C} 18: 1$; $\mathrm{C} 18: 2$; and $\mathrm{C} 18: 3$. C16:0 increased as the fruit ripened in 'Jerac' and 'Clipper', while C18:2 increased in the former and decreased markedly in the latter (Table 2). The main change occurred in 'Clipper' between the preclimacteric and postclimacteric stages in $\mathrm{C} 18: 2$ and $\mathrm{C} 18: 3$ fatty acids; there was a concomitant increase in C18:2 and decrease in C18:3.

Some indications about the membrane fluidity could be obtained by expressing the results as various ratios usually used to characterize the saturation of fatty acids (Lurie and Ben Arie, 1983). The double-bond index showed little differences from stage to stage of ripening (Table 3 ), and the saturated to unsaturated fatty acid ratio remained relatively constant in both varieties. However, the ratio linolenic (C18:3) to linoleic (C18:2) acid increased in 'Clipper' as fruit ripened. This ratio decreased consistently in 'Jerac' falling by $50 \%$ at the postclimacteric stage.

\section{Discussion}

As usual in climacteric fruit, both muskmelon varieties were characterized by transient increases in respiration (Fig. 1), which coincided with an increase in $\mathrm{C}_{2} \mathrm{H}_{4}$ biosynthesis (Fig. 2) under all experimental conditions. In contrast, Shellie and Saltveit (1993) have shown on other muskmelon varieties that fruit attached to the plant did not exhibit an increase in respiration. These authors concluded that the increase in $\mathrm{CO}_{2}$ production may be a consequence of harvest and that the peak in $\mathrm{C}_{2} \mathrm{H}_{4}$ biosynthesis might provide a better characterization of climacteric or nonclimacteric fruit. Our results show that the pattern for $\mathrm{C}_{2} \mathrm{H}_{4}$ biosynthesis was slightly different in both varieties and indicated that there is some dissociation of the $\mathrm{C}_{2} \mathrm{H}_{4}$ burst and the climacteric event as pointed out by Güçlü et al. (1989) for tomatoes. Although 'Jerac' exhibited a pattern of climacteric fruit-an increase of $\mathrm{C}_{2} \mathrm{H}_{4}$ production followed by a drop, 'Clipper' maintained high $\mathrm{C}_{2} \mathrm{H}_{4}$ synthesis until senescence, suggesting that $\mathrm{C}_{2} \mathrm{H}_{4}$ biosynthesis is not closely related to muskmelon storage life. This lack of correlation between $\mathrm{C}_{2} \mathrm{H}_{4}$ production and storage life has also been reported by Kendall and $\mathrm{Ng}$ (1988), who showed differences in rates of $\mathrm{C}_{2} \mathrm{H}_{4}$ production in netted and nonnetted melons and concluded that $\mathrm{C}_{2} \mathrm{H}_{4}$ production is genetically controlled. In the same way, Gussman et al. (1993) reported that long-storing apple genotypes produced considerable amounts of $\mathrm{C}_{2} \mathrm{H}_{4}$ during ripening.

An indication of the extent of any membrane perturbation was followed by measuring total electrolyte leakage from similar sets of pulp discs. The general increase in electrolyte leakage (Fig. 3) in 'Jerac' reflects an increase in membrane permeability during ripening and reflects a loss of the mesocarp integrity. In apples, Lurie and Ben Arie (1983) reported similar increases in permeability between the preclimacteric and climacteric stages, which coincided with increased membrane microviscosity. The low and constant loss of solutes in 'Clipper' suggests that membrane integrity is not affected at least during the major part of the ripening.

Changes in the membrane permeability are strongly related to changes in the composition of the lipid matrix. During the senescence of rose petals, Borochov et al. (1982) have shown a relationship between an increase in the sterol-phospholipid ratio and a decrease of membrane fluidity. In apples, changes in the integrity of microsomal membranes are correlated with increased concentration of total free sterol and increased fatty acids saturation level of phospholipids (Lurie et al., 1987). A substantial increase of the total sterol content has also been reported in tomato (Whitaker, 1988). It seems that sterol rigidifies the unsaturated acyl chains of phospholipids inducing a gel phase formation in the membrane and

Table 1. Sterol and phospholipid content in the microsomal fraction of the mesocarp tissues of nonnetted muskmelons during ripening. Means of five experiments \pm SE.

\begin{tabular}{|c|c|c|c|}
\hline $\begin{array}{l}\text { Ripeness } \\
\text { stage }\end{array}$ & $\begin{array}{c}\text { Sterol } \\
\left(\mathrm{mg} \cdot \mathrm{g}^{-1} \text { dry wt) }\right.\end{array}$ & $\begin{array}{l}\text { Phospholipid } \\
\left(\mathrm{mg} \cdot \mathrm{g}^{-1} \text { dry wt) }\right.\end{array}$ & $\begin{array}{l}\text { Sterol-phospholipid } \\
\text { ratio }\end{array}$ \\
\hline \multicolumn{4}{|c|}{ Jerac } \\
\hline Preclimacteric & $0.35 \pm 0.05$ & $2.25 \pm 0.15$ & 0.15 \\
\hline Climacteric & $0.60 \pm 0.07$ & $1.65 \pm 0.09$ & 0.36 \\
\hline Postclimacteric & $0.70 \pm 0.05$ & $1.35 \pm 0.06$ & 0.52 \\
\hline \multicolumn{4}{|c|}{ Clipper } \\
\hline Preclimacteric & $0.32 \pm 0.02$ & $1.85 \pm 0.05$ & 0.17 \\
\hline Cclimacteric & $0.30 \pm 0.05$ & $1.70 \pm 0.08$ & 0.18 \\
\hline Postclimacteric & $0.35 \pm 0.03$ & $1.70 \pm 0.07$ & 0.20 \\
\hline
\end{tabular}


Table 2. Changes in fatty acid content of the phospholipids in the microsomal fraction of muskmelon mesocarp during ripening. Means of five experiments, SE in parentheses.

\begin{tabular}{|c|c|c|c|c|c|c|c|c|}
\hline \multirow{2}{*}{$\begin{array}{l}\text { Ripeness } \\
\text { stage }\end{array}$} & \multicolumn{5}{|c|}{ Fatty acids (\%) } & \multirow{2}{*}{$\begin{array}{c}\text { Saturated-to- } \\
\text { unsaturated } \\
\text { ratio }\end{array}$} & \multirow{2}{*}{$\begin{array}{c}\text { Double- } \\
\text { bond } \\
\text { index }\end{array}$} & \multirow{2}{*}{$\begin{array}{r}18: 3 / \\
18: 2\end{array}$} \\
\hline & $16: 0$ & $18: 0$ & $18: 1$ & $18: 2$ & $18: 3$ & & & \\
\hline \multicolumn{9}{|c|}{ Jerac } \\
\hline Preclimacteric & $\begin{array}{c}23 \\
(1.8)\end{array}$ & $\begin{array}{c}4 \\
(0.4)\end{array}$ & $\begin{array}{l}20.5 \\
(1.9)\end{array}$ & $\begin{array}{c}19 \\
(1.3)\end{array}$ & $\begin{array}{c}31 \\
(2.2)\end{array}$ & 0.37 & 1.51 & 1.63 \\
\hline Climacteric & $\begin{array}{l}26 \\
(2)\end{array}$ & $\begin{array}{c}3.5 \\
(0.3)\end{array}$ & $\begin{array}{c}21 \\
(1.5)\end{array}$ & $\begin{array}{c}24 \\
(1.6)\end{array}$ & $\begin{array}{l}22 \\
(2)\end{array}$ & 0.44 & 1.35 & 0.92 \\
\hline Postclimacteric & $\begin{array}{c}27 \\
(2.1)\end{array}$ & $\begin{array}{c}3.5 \\
(0.2)\end{array}$ & $\begin{array}{c}20 \\
(1.1)\end{array}$ & $\begin{array}{c}30 \\
(1.6)\end{array}$ & $\begin{array}{c}16 \\
(0.9)\end{array}$ & 0.46 & 1.28 & 0.53 \\
\hline \multicolumn{9}{|c|}{ Clipper } \\
\hline Preclimacteric & $\begin{array}{l}22 \\
\text { (1) }\end{array}$ & $\begin{array}{c}2.5 \\
(0.2)\end{array}$ & $\begin{array}{c}20 \\
(1.1)\end{array}$ & $\begin{array}{c}28 \\
(1.7)\end{array}$ & $\begin{array}{c}24 \\
(1.5)\end{array}$ & 0.34 & 1.48 & 0.86 \\
\hline Climacteric & $\begin{array}{c}24 \\
(1.5)\end{array}$ & $\begin{array}{c}2 \\
(0.2)\end{array}$ & $\begin{array}{l}19.5 \\
(1.5)\end{array}$ & $\begin{array}{c}23 \\
(1.4)\end{array}$ & $\begin{array}{c}28 \\
(1.7)\end{array}$ & 0.37 & 1.49 & 1.22 \\
\hline Postclimacteric & $\begin{array}{c}26 \\
(1.9)\end{array}$ & $\begin{array}{c}2 \\
(0.1)\end{array}$ & $\begin{array}{c}18 \\
(1.2)\end{array}$ & $\begin{array}{c}19 \\
(0.9)\end{array}$ & $\begin{array}{l}31.5 \\
(1.7)\end{array}$ & 0.41 & 0.87 & 1.66 \\
\hline
\end{tabular}

an increase in membrane permeability. In netted muskmelon plasma membrane (Lester and Stein, 1993), the loss of membrane permeability was associated with increased total free sterolphospholipid ratio and increased fatty acid saturation level. Our results show that in nonnetted muskmelons, there are also changes in the lipid components of the mesocarp microsomal membranes during ripening (Tables 1 and 2). However, our conclusions are based on the assumption that data obtained with microsomal membranes of muskmelon are indicative of changes in whole membrane lipid level. It is not ruled out that changes in a specific membrane do not appear with experiments on overall membranes. In 'Jerac', the increase of membrane permeability may be related to a concomitant elevation of the sterol level and a breakdown of phospholipids (Table 1). Moreover, the slight decrease in the 18:3/ 18:2 ratio particularly between the preclimacteric and climacteric stages (Table 2) reflects an increase in the fatty acid saturation and could contribute to the loss of membrane fluidity. The behavior of the lipid composition in 'Clipper' was unusual in a senescing organ since the sterol-phospholipid ratio was constant and the degree of saturation of fatty acid decreased tending to increase the membrane fluidity. Indeed, a similar behavior of the lipid composition has been described in potato tubers since increased degree of unsaturation of membrane fatty acids in response to low temperature appeared to increase membrane permeability during storage, but it was a beneficial acclimation response and not a senescence process (Spychalla and Desborough, 1990). Here, the absence of major change in sterol and phospholipids content and the high level of fatty acid unsaturation in 'Clipper' suggest that membrane permeability is not really affected during the ripening. This is consistent with the low loss of solutes measured and could contribute to the long storage life of 'Clipper'. Furthermore, the maintenance of membrane integrity could explain the high $\mathrm{C}_{2} \mathrm{H}_{4}$ production until senescence since there is evidence (Field, 1981; Mayne and Kende, 1986; Bouzayen et al., 1990) that ACC oxidase, the enzyme that converts $\mathrm{ACC}$ to $\mathrm{C}_{2} \mathrm{H}_{4}$, requires tonoplast and plasmalemma integrity. ACC oxidase activity may be, in some aspects, a measure of relative membrane integrity.

In conclusion, our results agree with the idea that ripening and senescence are the result of lipid changes. It seems that, in nonnetted muskmelons, changes in membrane lipid composition associated to a gel phase formation in the membrane may be responsible for the loss of membrane permeability and, consequently, affect postharvest storage life. Moreover, this opens the way to elucidating the significance of $\mathrm{C}_{2} \mathrm{H}_{4}$ production in 'Clipper' and to understanding the role of $\mathrm{C}_{2} \mathrm{H}_{4}$ as a trigger to the ripening process. Further work should also be to understand the mechanism involved in the membrane protection during ripening.

\section{Literature Cited}

Ames, B.N. 1966. Assay of inorganic phosphate, total phosphate and phosphatases. Methods Enzymol. 8:115-118.

Bligh, E.G. and W.J. Dyer. 1959. A rapid method of total lipid extraction and purification. Can. J. Biochem. Physiol. 37:911-917.

Bouzayen, M., A. Latché, and J.C. Pech. 1990. Subcellular localization of the sites of conversion of 1-aminocyclopropane-1-carboxylic acid into ethylene in plant cells. Planta 180:175-180.

Borochov, A., A.H. Halevy, and M. Shinitzky. 1982. Senescence and the fluidity of rose petals membranes. Plant Physiol. 69:296-299.

Brady, C.J. 1987. Fruit ripening. Annu. Rev. Plant Physiol. Plant Mol. Biol. 38:155-178.

Droillard, M.J., A. Paulin, and J.C. Massot. 1987. Free radical production, catalase and superoxide dismutase activities and membrane integrity during senescence of petals of cut carnations (Dianthus caryophyllus). Physiol. Plant. 71:197-202.

Field, R.J. 1981. A relationship between membrane permeability and ethylene production at high temperature in leaf tissue of Phaseolus vulgaris L. Ann. Bot. 48:33-39.

Grunwald, C. 1970. Sterol distribution in intracellular organelles isolated from tobacco leaves. Plant Physiol. 45:663-666.

Güçlü, J., A. Paulin, and P. Soudain. 1989. Changes in polar lipids during ripening and senescence of cherry tomato (Lycopersicon esculentum): Relation to climacteric and ethylene increases. Physiol. Plant. 77:413-419. Gussman, C.D., J.C. Goffreda, and T.J. Gianfagna. 1993. Ethylene production and fruit-softening rates in several apple fruit ripening variants. HortScience 28:135-137.

Kendall S.A. and T.J. Ng. 1988. Genetic variation of ethylene production in harvested muskmelon fruits. HortScience 28:759-761.

Lester, G. 1990. Lipoxygenase activity of hypodermal- and middlemesocarp tissues from netted muskmelon fruit during maturation and storage. J. Amer. Soc. Hort. Sci 115:612-615.

Lester, G. and E. Stein. 1993. Plasma membrane physicochemical changes during maturation and postharvest storage of muskmelon fruit. J. Amer. Soc. Hort. Sci. 118:223-227. 
Lurie, S and R. Ben-Arie. 1983. Microsomal membrane changes during the ripening of apple fruit. Plant Physiol. 73:636-638.

Lurie, S. and J.D. Klein. 1990. Heat treatment of ripening apples: Differential effects on physiology and biochemistry. Physiol. Plant. 78:181186.

Lurie, S, L. Sonego, and R. Ben-Arie. 1987. Permeability, microviscosity and chemical changes in the plasma membrane during storage of apple fruit. Scientia Hort. 32:73-83.

Mayne, R.G. and H. Kende. 1986. Ethylene biosynthesis in isolated vacuoles of Vicia faba L. - Requirement for membrane integrity. Planta
167:159-165.

Romani, R.J. 1984. Respiration, ethylene, senescence and homeostasis as an integrate view of postharvest life. Can. J. Bot. 62:2950-2955.

Shellie, K.C. and M.E. Saltveit, Jr. 1993. The lack of a respiratory rise in muskmelon fruit ripening on the plant challenges the definition of climacteric behaviour. J. Expt. Bot. 44:1403-1406.

Spychalla, J.P. and S.L. Desborough. 1990. Fatty acids, membrane permeability, and sugars of stored potato tubers. Plant Physiol. 94:1207-1213.

Whitaker, B.D. 1988. Changes in the steryl lipid content and composition of tomato fruit during ripening. Phytochemistry 27:3411-3416. 